\title{
Trusting Scientists More Than the Government New Hampshire Perceptions of the Pandemic
}

\author{
Lawrence C. Hamilton and Thomas G. Safford
}

The Carsey Perspectives series presents new ways of looking at issues affecting our society and the world. Any opinions, findings, and conclusions or recommendations expressed in this material are those of the authors and do not necessarily reflect the views of the sponsors or publisher.

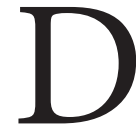
espite a dramatic increase in the incidence of COVID-19, and an evolving government response, there was no significant change between surveys taken in mid-March and mid-April in the shares of New Hampshire residents who reported they were making "major changes" in their daily routines, had low confidence in the federal government's response, or expressed trust in information from science agencies.

From March 17 to March 26 Carsey School researchers surveyed 650 Granite State residents, asking about the growing crisis. Seventy-seven percent said they were already making major changes to their daily routine, such as leaving home less often. Only 46 percent said they were somewhat (27 percent) or very (19 percent) confident in the federal government's ability to respond effectively to the situation, but 77 percent said that they trusted science agencies such as the Centers for Disease Control (CDC) as sources of information about the coronavirus. ${ }^{1}$ This survey wrapped up just as the governor issued a statewide stay-at-home order (March 26). During the 10-day survey period, the total number of confirmed cases in New Hampshire had risen from 26 to 158.

In the following month, a second statewide survey (April 16 to April 20) repeated the COVID-19 questions. By this time, the pandemic had substantially advanced; the state's total number of confirmed cases rose from 1,211 to 1,447 during the 5-day April survey period, with 50 to 76 new cases confirmed every day. Despite rapidly changing conditions, survey responses were statistically the same: 79 percent reported making major changes, 47 percent expressed confidence in the federal government's ability to respond, and 72 percent trusted information from science agencies (Figure 1$){ }^{2}$ Although the seven-day average of new COVID-19 cases had

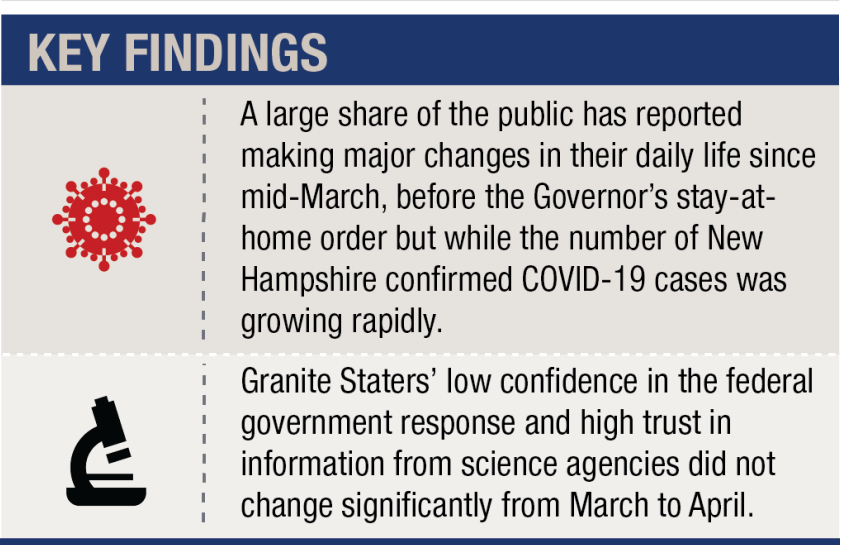

FIGURE 1. PERCENTAGE OF RESPONDENTS WHO MADE MAJOR CHANGES IN THEIR DAILY ROUTINE, ARE SOMEWHAT OR VERY CONFIDENT IN THE FEDERAL GOVERNMENT'S ABILITY TO RESPOND EFFECTIVELY, AND EXPRESS TRUST IN SCIENCE AGENCIES FOR INFORMATION ABOUT THE CORONAVIRUS (COMPARING MARCH 17-26 AND APRIL 16-20 SURVEYS)

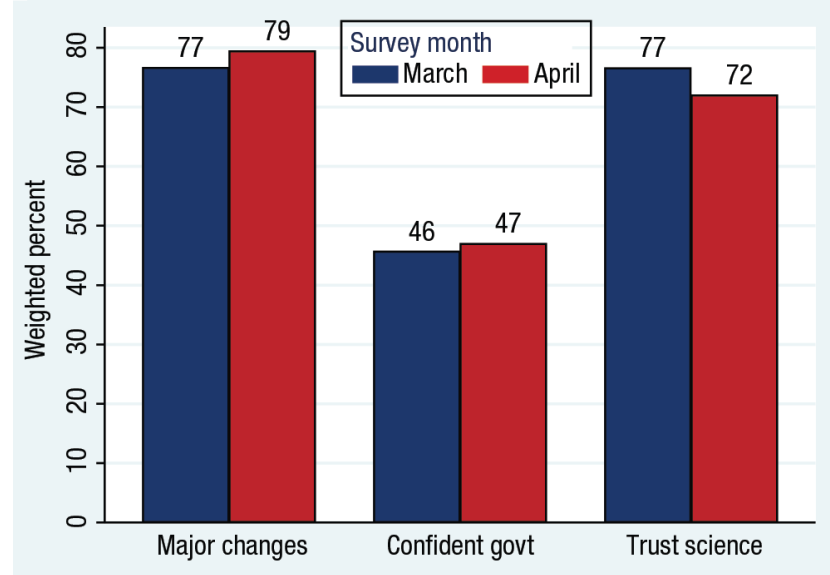

Source: March/April 2020 Granite State Panel surveys, $n=1,805$

earlier fallen, starting 10 days after the stay-at-home order, counts were now climbing again. Social distancing and staying at home bought time by flattening the exponential growth, but they did not stop or reverse the pandemic's spread in New Hampshire (Figure 2). 
FIGURE 2. NEW HAMPSHIRE NEW CONFIRMED CASES OF COVID-19, DAILY FROM MARCH 8 TO MAY 3, WITH DATES OF THE MARCH AND APRIL UNH SURVEYS

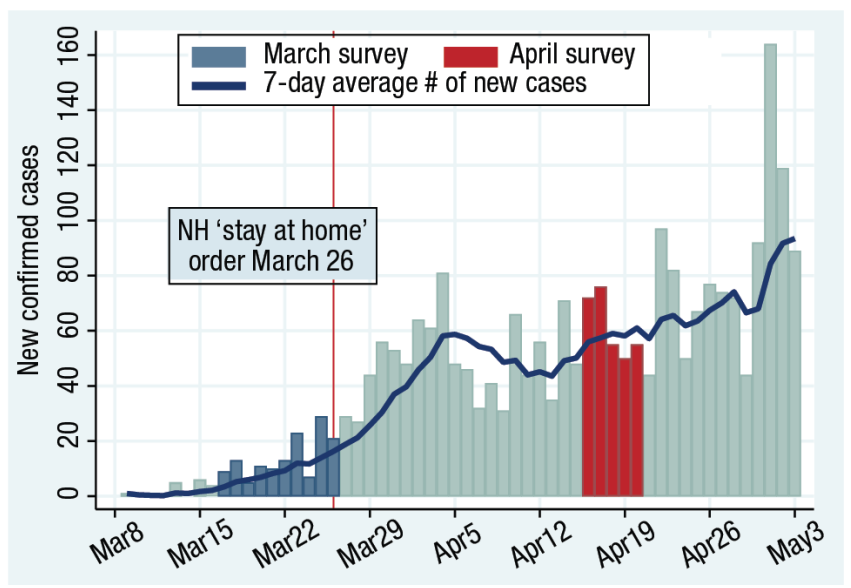

Source: NH Department of Health and Human Services

To understand this stability in coronavirus views, and what it could mean for the future, we need a longer perspective. For more than a decade, nationwide and regional surveys have found that scientists are viewed favorably by a majority of Americans-but with persistent political divisions. Conservatives tend to be less likely, while moderates and liberals are more likely, to say they trust scientists for information across a range of topics from climate change and evolution to nuclear power safety and vaccines. ${ }^{3}$ Because vaccine development presents our main hope for turning back COVID-19, public objections to vaccine research or deployment, linked to sociopolitical identity, ${ }^{4}$ could pose a substantial challenge for the country's future. Similar challenges are raised by political divisions in public perceptions of the Centers for Disease Control (CDC), historically the premier U.S. agency for fighting pandemics, ${ }^{5}$ and by political divisions regarding social distancing and stay-at-home restrictions-the most effective tool available right now. ${ }^{6}$

In terms of the three questions charted in Figure 1, liberals are most likely and conservatives least likely to trust scientists for information about the coronavirus. Conversely, liberals are least likely and conservatives most likely to express confidence in the Trump administration's ability to respond effectively. ${ }^{7}$ These preferences have policy implications, in that medical scientists strongly advise against easing restrictions too soon, while President Trump has urged his followers to protest restrictions, and proposed that they soon be relaxed.
Figure 3 visualizes the effect that views of scientists and the current federal government have on the most basic behavior, whether people individually made major changes to their daily routines because of the virus. Probabilities of major changes range from more than 90 percent among people who trust scientists and have no confidence in this government, to less than 50 percent among those who do not trust scientists and are very confident in this government.

\section{FIGURE 3. PERCENTAGE OF RESPONDENTS MAKING MAJOR CHANGES IN THEIR DAILY ROUTINE, BY VIEWS OF SCIENCE AGENCIES AND FEDERAL GOVERNMENT (COMBINED MARCH AND APRIL SURVEY DATA)}

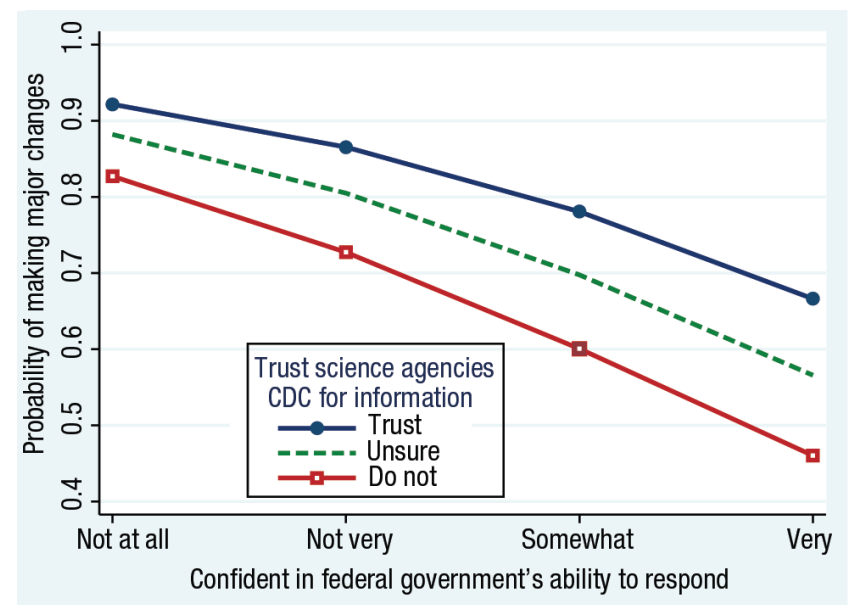

Source: March/April 2020 Granite State Panel surveys, $n=1,736$

Taking this analysis a step further, we could expect those with high confidence in the Trump administration and no trust in scientists to respond quickly as legal restrictions are lifted, regardless of what scientists are saying-potentially fueling a new stage of contagion like the early weeks of Figure 2 but at higher levels. On the other hand, people with low confidence in the administration may share scientists' more cautious view, and hold back from resuming many of their pre-coronavirus activities even when these are allowed. Longstanding U.S. political divisions on science, previously observed across many different fields, will now shape whether and how the country recovers from this pandemic. 


\section{Methods}

Both surveys were conducted by the Survey Center at the University of New Hampshire, using their Granite State Panel online sampling. Probability weights, employed with all analysis in this brief, make adjustments to give more representative results. For survey question wording, see Safford and Hamilton (2020).

The 1,155 survey respondents in April include 496 who had also responded in March, along with 659 others contributing for the first time in April. Whether repeat respondents are set aside or kept in our analysis, the basic conclusions are stable: there are no significant differences between March and April responses on any of the three questions asked.

Probabilities in Figure 3 are calculated from a statistical analysis (weighted logit regression) that adjusts for variations in respondent age, sex, and education. Education makes no detectable difference, but the analysis finds that women are significantly more likely, and young adults significantly less likely, to report having changed their behavior.

\section{Endnotes}

1. T.G. Safford and L.C. Hamilton, "Views of a fast-moving pandemic: A survey of Granite Staters' responses to COVID-19" (Durham, NH: Carsey School of Public Policy, University of New Hampshire, 2020). http://scholars.unh. edu/carsey/396

2. Although the percentage reporting "major changes" remained almost the same in March and April, the meaning of this expression had shifted. In March, people were cutting back travel plans and going out less often; in April, they were staying home from work. In either case, however, making "major changes" would be in compliance with science-based advice at the time.

None of the changes in Figure 1 are statistically significant, but the 5-point decline in trust for science agencies such as the CDC overshadows the 1- or 2-point shifts on other questions. This decline might reflect growing recognition that the CDC, under Trump-appointed director Robert Redfield, had badly mishandled testing and response during the early days of the pandemic. For a timeline see "What we know about delays in coronavirus testing" (Washington Post, April 18, 2020). https://www.washingtonpost.com/ investigations/2020/04/18/timeline-coronavirus-testing
3. L.C. Hamilton, "Conservative and liberal views of science: Does trust depend on topic?" (Durham, NH: Carsey School of Public Policy, University of New Hampshire, 2015). http:// scholars.unh.edu/carsey/252/

4. L.C. Hamilton, J. Hartter, and K. Saito, "Trust in scientists on climate change and vaccines," Sage Open, 2015. https:// journals.sagepub.com/doi/10.1177/2158244015602752

5. L.C. Hamilton and T.G. Safford, "Ideology affects trust in science agencies during a pandemic" (Durham, NH: Carsey School of Public Policy, University of New Hampshire, 2020). http://scholars.unh.edu/carsey/391

6. Safford and Hamilton, 2020.

7. Safford and Hamilton, 2020.

\section{Related Publications}

"Views of a Fast-Moving Pandemic: A Survey of Granite Staters' Responses to COVID-19"

(April 2020)

"Ideology Affects Trust in Science Agencies During a Pandemic"

(March 2020)

"The Zika Virus Threat: How Concerns About Scientists May Undermine Efforts to Combat the Pandemic"

(March 2017)

"Conservative and Liberal Views of Science: Does Trust Depend on Topic?"

(September 2015)

\section{About the Authors}

Lawrence C. Hamilton is professor of sociology and senior fellow at the Carsey School of Public Policy at the University of New Hampshire.

Thomas G. Safford is associate professor of sociology and faculty fellow at the Carsey School of Public Policy at the University of New Hampshire.

\section{Acknowledgments}

Support for coronavirus questions on the Granite State Panel survey was provided by the College of Liberal Arts at the University of New Hampshire. 
4 CARSEY SCHOOL OF PUBLIC POLICY

\section{University of New Hampshire}

1.i. Carsey School of Public Policy

The Carsey School of Public Policy at the University of New Hampshire is nationally recognized for its research, policy education, and engagement. The school takes on the pressing issues of the twenty-first century, striving for innovative, responsive, and equitable solutions.

Huddleston Hall • 73 Main Street • Durham, NH 03824

(603) 862-2821

TTY UsERS: DIAL 7-1-1 OR 1-800-735-2964 (RELAY N.H.)

carsey.unh.edu 